5-16-2018

\title{
Rethinking the Ken Through the Lens of Psychological Science
}

Jason M. Chin

TC Beirne School of Law, University of Queensland

William E. Crozier

Duke University

Follow this and additional works at: https://digitalcommons.osgoode.yorku.ca/ohlj

Part of the Criminal Procedure Commons, and the Law and Psychology Commons Article

\section{(c) (1) $(9)$}

This work is licensed under a Creative Commons Attribution-Noncommercial-No Derivative Works 4.0 License.

\section{Citation Information}

Chin, Jason M. and Crozier, William E.. "Rethinking the Ken Through the Lens of Psychological Science." Osgoode Hall Law Journal 55.3 (2019) : 625-664.

https://digitalcommons.osgoode.yorku.ca/ohlj/vol55/iss3/1

This Article is brought to you for free and open access by the Journals at Osgoode Digital Commons. It has been accepted for inclusion in Osgoode Hall Law Journal by an authorized editor of Osgoode Digital Commons. 


\title{
Rethinking the Ken Through the Lens of Psychological Science
}

\begin{abstract}
Canadian courts regularly exclude psychological expert evidence that would explain the factors that produce mistaken eyewitness identifications and false confessions (two significant sources of wrongful convictions). Courts justify these exclusions on the basis that the evidence is not beyond the ken of the trier of fact-the psychologist would simply be describing an experience shared by the judge and jury. In this article, the authors suggest this reasoning rests on two fundamental misunderstandings of psychology: unconscious neglect and dispositionism. In other words, judges mistakenly assume the trier of fact understands the unconscious situational forces that distort memories and cause innocent people to confess. Moreover, judges appear to prefer dispositional evidence of some disorder or syndrome suffered by the accused or by the witness to the crime. After demonstrating evidence of such reasoning in several decisions, the authors suggest reforms based on a more nuanced understanding of human psychology.
\end{abstract}

\section{Keywords}

Evidence, Expert; Forensic psychology

Creative Commons License (c) (i) (9)

This work is licensed under a Creative Commons Attribution-Noncommercial-No Derivative Works 4.0 License. 


\title{
Rethinking the Ken Through the Lens of Psychological Science
}

\author{
JASON M. CHIN*AND WILLIAM E. CROZIER ${ }^{* *}$
}

Canadian courts regularly exclude psychological expert evidence that would explain the factors that produce mistaken eyewitness identifications and false confessions (two significant sources of wrongful convictions). Courts justify these exclusions on the basis that the evidence is not beyond the ken of the trier of fact-the psychologist would simply be describing an experience shared by the judge and jury. In this article, the authors suggest this reasoning rests on two fundamental misunderstandings of psychology: unconscious neglect and dispositionism. In other words, judges mistakenly assume the trier of fact understands the unconscious situational forces that distort memories and cause innocent people to confess. Moreover, judges appear to prefer dispositional evidence of some disorder or syndrome suffered by the accused or by the witness to the crime. After demonstrating evidence of such reasoning in several decisions, the authors suggest reforms based on a more nuanced understanding of human psychology.

Lecturer, TC Beirne School of Law, University of Queensland; Affiliated Lecturer, School of Psychology, University of Queensland.

** Post-Doctoral Research Associate, Duke University, NC USA.

This article deeply benefited from insights provided by Heather Douglas, Caitlin Goss, Saul Kassin, and John Monahan. We are also grateful for the incisive feedback of two anonymous reviewers and the Osgoode Hall Law Journal editors and editorial board. Conversations with Richard Kemp and Kristy Martire at the annual meeting of the Evidence-Based Forensics Initiative in Wollongong, New South Wales were critical in the early stages of this article. 


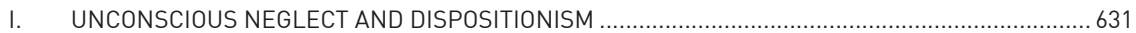

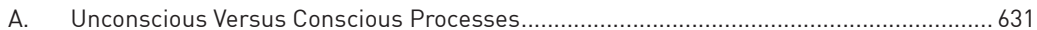

B. Social Psychology and the Non-Intuitive Power of the Situation ...................................633

C. Applied Social and Cognitive Psychology on Eyewitness

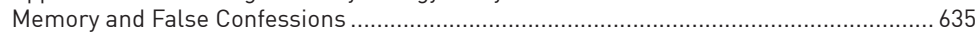

II. UNCONSCIOUS NEGLECT AND DISPOSITIONISM IN EXPERT EVIDENCE LAW..............................6 640

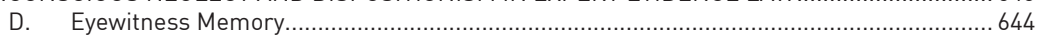

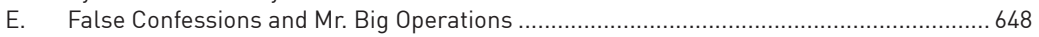

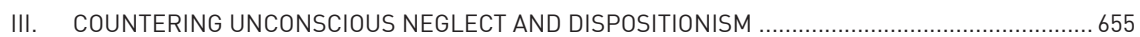

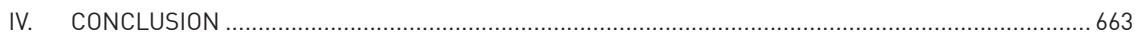

Outside consciousness there rolls a vast tide of life, which is, perhaps, even more important to us than the little isle of our thoughts which lies within our ken. ${ }^{1}$

CANADA, LIKE MANY JURISDICTIONS, relies on a "beyond the ken" standard to determine if expert evidence is necessary, and thus admissible, in court. ${ }^{2}$ In other words, expert evidence may only be admitted if it is likely to be outside the experience of the trier of fact. Fields like forensic science and pathology usually meet this standard, and, thus, experts in these fields regularly appear in court. However, psychological scientists—apart from some clinicians—face a

1. E S Dallas, The Gay Science (London: Chapman and Hall, 1866) at 207, cited in Timothy D Wilson, Strangers to Ourselves: Discovering the Adaptive Unconscious (Cambridge, Mass: Belknap Press of Harvard University Press, 2002) at 17.

2. Rv Mohan, [1994] 2 SCR 9 at 23, 114 DLR (4th) 419 [Mohan]. In the United States, the Federal Rules of Evidence overturned the common law beyond the ken standard. However, David Kaye and colleagues note that "many—perhaps most" US courts continue to apply the old common law rule. See David H Kaye, David E Bernstein \& Jennifer L Mnookin, The New Wigmore: A Treatise on Evidence - Expert Evidence, 2nd ed, Richard D Friedman, ed (New York: Aspen Publishers, 2011) at 39. Similarly, in Australia, the Uniform Evidence Law abolished the requirement that opinion evidence go beyond common knowledge. For an example of this in New South Wales, see Evidence Act 1995 (NSW), s 80(b). Still, common law states retain the beyond common knowledge requirement and regularly exclude psychological scientific evidence on that basis. See $R v L M$, [2004] QCA 192. And, as in the United States, even states that have adopted the Uniform Evidence Law still retain the common knowledge distinction to some extent. See J D Heydon, Cross on Evidence, 10th ed (Chatswood, NSW: LexisNexis Butterworths, 2015) at 237-39, 1018-24. 
good deal more difficulty. ${ }^{3}$ This tendency has received a considerable amount of academic criticism because these psychologists would often opine on psychological phenomena that contribute to wrongful convictions, especially eyewitness memory and false confessions. ${ }^{4}$ Our contribution to this field, which forms the subject matter of this article, is an explanation for why judges tend to find that psychological science is within the trier of fact's ken and why that decision is mistaken.

In determining whether evidence is beyond the ken, courts fall prey to two fundamental misunderstandings about human psychology. First, they neglect the unconscious processes ${ }^{5}$ that underlie our behaviours and emotions. Second, courts discount the power of the situation in favour of a dispositional model of human psychology. As a result, judges regularly exclude experts because of the assumption that jurors are fully equipped to understand those unconscious and situational forces. They reason that those psychological forces form part of the everyday human experience, and, thus, jurors already know all they need to know. But, as E.S. Dallas noted in the above quotation that opened this article, this approach wrongly restricts jurors' view of human nature to that which is within our conscious ken. To take an example from the eyewitness memory field, the leading Canadian judgment drew a strict line between evidence about the situational forces that cause misremembering and disorders, like autism, that

3. For a review, see David M Paciocco, "Coping with Expert Evidence About Human Behaviour" (1999) 25:1 Queen's LJ 305; Gary T Trotter, "False Confessions and Wrongful Convictions" (2003-2004) 35:2 Ottawa L Rev 179; Timothy E Moore \& Cindy R Wasser, "Social Science and Witness Reliability: Reliable Science Begets Reliable Evidence" (2006) 33 CR (6th); Jill Copeland, "Helping Jurors Recognize the Frailties of Eyewitness Identification Evidence" (2002) 46:2 Crim LQ 188; Lisa Dufraimont, "Regulating Unreliable Evidence: Can Evidence Rules Guide Juries and Prevent Wrongful Convictions?” (2008) 33:2 Queen's LJ 261; Emma Cunliffe, "Without fear or favour? Trends and possibilities in the Canadian approach to expert human behaviour evidence" (2006) 10:4 Intl J Evidence \& Proof 280.

4. Copeland, supra note 3; Trotter, supra note 3 at 193; Dufraimont, supra note 3 at 312, 321-26; Amy D Trenary, "State v. Henderson: A Model for Admitting Eyewitness Identification Testimony" (2013) 84:4 U Colo L Rev 1257.

Compare Lee Stuesser, "Experts on Eyewitness Identification: I Just Don't See It" (2006) 31:3 Man LJ 543 (for an argument that psychological scientific evidence is unnecessary).

5. In using the term unconscious, we are referring to the concept as it has been explored in decades of cognitive scientific research on mental processes that evade conscious reflection. This conception contrasts with the lay (and Freudian) meaning of the word often associated with sublimated desires. 
impact memory. ${ }^{6}$ The situational evidence is inadmissible because all jurors have memories and all have experienced forgetting. ${ }^{7}$ Disposition is admissible because most jurors have not experienced autism. ${ }^{8}$

This approach represents a facile and incorrect view of psychology. Rather, humans cannot report on what the unconscious parts of their brains are up to and are, in fact, oblivious to those processes. For similar reasons, they are often unaware of the situational forces that profoundly impact their lives. As hundreds of wrongful convictions demonstrate, people do not naturally think like psychological scientists and, thus, require assistance in evaluating testimony that engages well-established and replicated psychological findings. We now define these two misunderstandings of human psychology—unconscious neglect and dispositionism - prior to providing an outline for this article.

Several decades of psychology research have converged on two truths that have been largely disregarded by conventional legal reasoning. ${ }^{9}$ First, a great deal of our thoughts, feelings, and behaviours are driven by unconscious processes that we cannot consciously access. And so, when we are asked to report on why we came to a certain judgment, we often confabulate reasons. Investigation into these processes has girded Nobel Prize-winning research on how economic markets work ${ }^{10}$ and has found that they are driven by unconscious heuristics that even leading academics long disregarded. ${ }^{11}$ For ease of reading, we refer

6. $R v$ McIntosh (1997), 35 OR (3d) 97 at para 21, 117 CCC (3d) 385 (CA) [McIntosh]. The court notes: "Expert evidence might be admissible to show that the witness is an autistic savant and that such exceptional memory feats are often associated with this syndrome" (ibid).

7. Ibid at para 20.

8. Ibid at para 21.

9. For a review of research that has sought to integrate social and cognitive psychology into legal scholarship, see Jon Hanson \& David Yosifon, "The Situation: An Introduction to the Situational Character, Critical Realism, Power Economics, and Deep Capture" (2003) 152:1 U Pa L Rev 129 [Hanson \& Yosifon, "The Situation"]; Jon Hanson \& David Yosifon, "The Situational Character: A Critical Realist Perspective on the Human Animal” (2004) 93:1 Geo LJ 1 [Hanson \& Yosifon, "The Situational Character"].

10. More recently, this research yielded important legal policy suggestions in the form of what researchers term "nudges." See Richard H Thaler \& Cass R Sunstein, Nudge: Improving Decisions About Health, Wealth, and Happiness (New York: Penguin Books, 2009). This research formed the basis of the 2017 Nobel Prize in Economics awarded to Thaler.

11. Daniel Kahneman \& Amos Tversky, "Prospect Theory: An Analysis of Decision under Risk" (1979) 47:2 Econometrica 263. 
to this failure to account for unconscious cognitive and affective processes as "unconscious neglect." 12

Second, most people fail to account for the psychological influence of situational forces and overestimate the role of disposition (psychologists know this phenomenon as the "fundamental attribution error"). ${ }^{13}$ In social and cognitive psychology, which has produced much of the research described herein, situational forces include demands that come from outside the individual, such as features of the environment and the presence or absence of other people. Disposition, on the other hand, comes from within. It encompasses personality characteristics ${ }^{14}$ and the presence of a psychological disorder. ${ }^{15}$

Thought, action, and emotion are, of course, driven by a complex interaction of situation and disposition: Certain types of people seek out certain types of situations, and, conversely, situational demands shape our personalities. But in any given instance, the role of situation or disposition may be isolated through careful empirical and experimental research. And, as we detail below in Part I, humans intuitively favour dispositional accounts of psychology. ${ }^{16}$ Indeed, situationism-

12. In coining this term, we were inspired by Daniel T Gilbert and colleagues' term "immune neglect," which represents the failure to account for unconscious processes that stabilize our emotions. See Daniel T Gilbert et al, "Immune Neglect: A Source of Durability Bias in Affective Forecasting" (1998) 75:3 J Personality \& Soc Psychol 617.

13. See e.g. Lee Ross \& Richard E Nisbett, The Person and the Situation: Perspectives of Social Psychology (London, UK: Pinter \& Martin, 2011); Hanson \& Yosifon, "The Situational Character," supra note 9 at 6-13. One well-studied instance of the fundamental attribution error is the inclination to attribute one's personal failings to some situational factor but attribute others' personal failings to their disposition. See Elliot Aronson, Timothy D Wilson \& Robin M Akert, Social Psychology, 4th ed (New Jersey: Prentice Hall, 2002) at 114-27. On the actor/observer difference, see also Edward E Jones \& Richard E Nisbett, "The Actor and the Observer: Divergent Perceptions of the Causes of Behaviour" in Edward E Jones et al, Attribution: Perceiving the Causes of Behavior (New Jersey: General Learning Press, 1972) at 79-94.

14. See generally Hans J Eysenck \& Michael W Eysenck, Personality and Individual Differences: A Natural Science Approach (New York: Plenum, 1985).

15. The study of mental disorders is typically conducted by clinical psychologists. For a methodological review of that field, see Jennifer L Tackett et al, "It's Time to Broaden the Replicability Conversation: Thoughts for and from Clinical Psychological Science" (2017) 12:5 Perspectives on Psychol Sci 742.

16. Ross \& Nisbett, supra note 13; Hanson \& Yosifon, "The Situational Character," supra note 9. 
recognition of the power of the situation-has only just begun to inform legal scholarship, with evidence law largely insulated from this perspective. ${ }^{17}$

As we discuss, experts may be proffered to explain the situational and unconscious factors that cause eyewitnesses to make mistakes ${ }^{18}$ and cause suspects to falsely confess to crimes. ${ }^{19}$ The decision to admit or exclude these experts carries serious stakes. Mistaken eyewitness identifications are present in approximately $70-80$ per cent of wrongful convictions, ${ }^{20}$ and false confessions are also surprisingly common. ${ }^{21} \mathrm{~A}$ better understanding of why courts deem these experts unnecessary is vital to charting a path forward in preventing wrongful convictions.

Now that we have set up the problem, Part I delves into the science of unconscious neglect and dispositionism. That background provides the foundation for Part II, wherein we discuss the influence of those forces on expert evidence doctrine. We focus on the psychology of eyewitness memory and false confessions for their criminal justice implications and demonstrable role in wrongful convictions. Finally, in Parts III and IV, we suggest a more flexible and concerted approach to unreliable Crown evidence that melds both exclusionary rules as well as measures designed to disabuse fact-finders of the misconceptions that flow from unconscious neglect and dispositionism.

17. In a review of the legal literature, Hanson and Yosifon remark that "[a]s a general matter, lay theories of human behavior, as well as legal theories, recognize the role of situation only when it is palpable or when theorists are particularly motivated to do so" (ibid at 6). Still, there is some acknowledgement of the role of the situation in evidence law. For instance, Justice Rosenberg, in $R v$ Clarke, discussed the probative value of character evidence through the lens of situationism. He found (correctly, in our view) that both situation and disposition inform behaviour. See $R v$ Clarke (1998), 129 CCC (3d) 1 at para 26, 112 OAC 233. Note also that Justice Rosenberg struck a situationist tone later in the judgment when he said that the jury should be told that a reputation for lying may not be predictive of perjury because "testifying in court under oath is a very different circumstance" (ibid at para 55).

18. David L Faigman, John Monahan \& Christopher Slobogin, "Group to Individual (G2i) Inference in Scientific Expert Testimony” (2014) 81:2 U Chicago L Rev 417 at 432-34.

19. Ibid at 467-68.

20. “Eyewitness Misidentification" (2017), The Innocence Project, online: <www.innocenceproject. org/causes/eyewitness-misidentification>; Brandon L Garrett, "Judging Innocence" (2008) 108:1 Colum L Rev 55 at 60.

21. Brandon L Garrett, "The Substance of False Confessions" (2010) 62:4 Stan L Rev 1051 [Garrett, "Substance"]. 


\section{UNCONSCIOUS NEGLECT AND DISPOSITIONISM}

The more we examine the mechanism of thought, the more we shall see that the automatic, unconscious action of the mind enters largely into all its processes. Our definite ideas are stepping-stones; how we get from one to the other, we do not know: something carries us; we do not take the step. ${ }^{22}$

Much psychological scientific research has concentrated on a simple but powerful finding: A lot of the time, we do not know the source of our behaviours, feelings, and conscious thoughts. This failure of self-knowledge contributes to dispositionism; we see behaviour as driven by internal mechanisms (i.e., dispositions) rather than less obvious situational forces. We correspondingly underestimate the impact of those situational forces.

In this Part, we first discuss the new science of the unconscious. As Oliver Wendell Holmes Sr. expressed in the above quotation, scientists have regularly contemplated the role that the unconscious plays in shaping our feelings and behaviours. But only in the last half-century or so have these processes received systematic empirical study. And much more recently still have legal scholars taken notice of these findings. We review these findings, specifically as they relate to expert evidence law. We then discuss how a failure to account for unconscious processes gives rise to dispositionism: discounting the role of the situation in favour of a character-based view of human behaviour. We end this Part with an application of these concepts to the science of eyewitness memory and false confessions. ${ }^{23}$

\section{A. UNCONSCIOUS VERSUS CONSCIOUS PROCESSES}

Over the past several decades, psychologists have uncovered increasing evidence about the significance and sheer amount of cognition that occurs unconsciously. A leading account draws a dichotomy between automatic and unconscious thinking (i.e., System 1), and conscious and controlled thinking (i.e., System 2). ${ }^{24}$ This research suggests that System 2 is just the tip of a vast iceberg of unconscious thinking. This powerful insight flows from Nobel Prize-winning

22. Oliver Wendell Holmes Sr, "Mechanism in Thought and Morals" (Address delivered before the Phi Beta Kappa Society of Harvard University, 29 June 1870), cited in Hanson \& Yosifon, "The Situational Character," supra note 9 at 32.

23. Faigman, Monahan \& Slobogin, supra note 18 at 425-26.

24. Daniel Kahneman, Thinking Fast and Slow (London: MacMillan, 2001); Michael J Saks \& Barbara A Spellman, The Psychological Foundations of Evidence Law (New York: New York University Press, 2016) at 19-22. 
work from psychologists Daniel Kahneman and Amos Tversky, whose research is well-known for its application to economic behaviour. ${ }^{25}$ They found that the longstanding assumption of the rational economic actor was regularly violated. Instead, subtle tweaks to the framing of an economic decision can vastly impact judgments and decisions. ${ }^{26}$ In other words, a great deal of economic behaviour is the product of unconscious heuristics and biases, or System 1.

A similar paradigm shift is underway in legal scholarship. For instance, Cass Sunstein and Richard Thaler recently applied the power of System 1 in a program of influence they refer to as "nudges." ${ }^{27}$ Nudge policies rely on unconscious processes to change behaviour without express rewards and punishments. ${ }^{28}$ For instance, making organ donation the default choice when applying for a driver's license dramatically increases that choice. ${ }^{29}$ Nudges do not seek to change a person's nature or disposition but rather subtly tweak the environment to alter behaviour. And, in fact, nudgees are not consciously aware they are being influenced; few, if any, of donors in the above scenario would report that they volunteered to be an organ donor because of the way the question was worded. ${ }^{30}$

Richard Nisbett and Timothy Wilson, in one of the most influential studies in psychology, added an important element to the understanding of unconscious thought: Humans cannot verbally report on it. ${ }^{31}$ In other words, not only does System 1 operate outside our awareness, but when we attempt to introspect as to why we did certain things, we often end up just making it up. Along with other experiments and a re-analysis of previous work, Nisbett and Wilson supported this insight in a very clever way. They performed a study, guised as research, on consumer preferences. They set up a table at a large department store with four sets of stockings. When customers approached the table, the researchers asked them to inspect the stockings and say which set they preferred and why.

25. Kahneman \& Tversky, supra note 11.

26. Ibid at 265-69.

27. Thaler \& Sunstein, supra note 10.

28. Ibid at 5-6.

29. Eric J Johnson \& Daniel Goldstein, “Do Defaults Save Lives?” (2003) 302:5649 Sci 1338.

30. The Canadian Department of Justice recently recognized unconscious bias in its new procedures for appointing federal judges. See Canada, Department of Justice, "Changes to the Appointments Process for Federal Judges” (20 January 2017), online: <www.justice.gc.ca/ eng/csj-sjc/scapq-pncsq.html>.

31. Richard E Nisbett \& Timothy DeCamp Wilson, “Telling More Than We Can Know: Verbal Reports on Mental Processes" (1977) 84:3 Psychol Rev 231. For a review of this study in the context of lay opinion evidence, see Jason M Chin, Jan Tomiska \& Chen Li, "Drawing the Line Between Lay and Expert Opinion Evidence" 63:1 McGill LJ [forthcoming in 2018]. 
The stockings on the far right of the table were the most popular, with shoppers saying, for instance, that they had a superior knit or simply felt the softest.

The genius of this study was that the stockings were all the same. Nisbett and Wilson had pretested the display and found that most people, when shopping, tend to gravitate towards items on the right. But only one of their participants realized this (that outlier was a psychology student), and the rest confabulated reasons for their decisions that could not be true considering these were identical stockings. In other words, these stocking-choosers, just like the organ donors encountering a choice framed in a subtly different way, were unconsciously influenced and, thus, could not provide the actual reason for their decisions. In short, we simply cannot report on what System 1 is up to. ${ }^{32}$

\section{B. SOCIAL PSYCHOLOGY AND THE NON-INTUITIVE POWER OF THE SITUATION}

Unconscious neglect gives rise to dispositionism. ${ }^{33}$ It is because we are unaware of the source of much of what we think and do that we fail to realize how deeply affected we are by the situation. The organ donor, for instance, fails to realize that a subtle tweak to the situation influenced his or her behaviour and instead ascribes the choice to a disposition: "I am the kind of person who wants to see my organs live on to help others." This, as Nisbett and Wilson so lucidly demonstrate, is a confabulation. In fact, Nisbett and Wilson's research sits in a field that, since its inception, has rigorously studied the situational influences that impact our behaviours in ways we do not account for. That field is social psychology.

32. See Kahneman, supra note 24. Daniel Kahneman provides a similar description of System 1 as unverbalizable:

When you are asked what you are thinking about, you can normally answer. You believe you know what goes on in your mind, which often consists of one conscious thought leading in an orderly way to another. But that is not the only way the mind works, nor indeed is that the typical way. Most impressions and thoughts arise in your conscious experience without your knowing how they got there (ibid at 4).

See also Wilson, supra note 1 . As we emphasize in the following paragraphs, it is not just that we lack introspective access to the reasons for our actions, but we also often generate the incorrect reasons. See infra note 58 and the accompanying text.

33. Hanson \& Yosifon, "The Situational Character," supra note 9 at 32, citing Mahzarin R Banaji, "Ordinary Prejudice" (2001) Psychological Sci Agenda 8 at 8. Banaji notes that "[c] onsciousness, the feature at the center of what makes humans unique, is the culprit [of our dispositionism], for it permits a view of who we are and what we are capable of that is independent of the knowledge and feelings that may drive beliefs, attitudes, and behaviour" (ibid). 
Social psychology arose, in part, as a reaction to World War II and the questions it prompted about the genesis of evil deeds. In particular, were the atrocities that were committed a product of bad people (i.e., disposition) or powerful situational forces? Such questions were explored in what is perhaps social psychology's paradigmatic set of studies: Stanley Milgram's obedience experiments. ${ }^{34}$ Milgram asked participants to give gradually increasing shocks to another participant (an employee of Milgram's lab who was not actually being shocked). The presumed shock recipient would protest, saying he had a heart condition, and even scream out towards the end. The device used by the participants contained multiple warnings that the shocks were dangerous. Still, the experimenter, cloaked in a white lab coat, urged the participants on, saying that they must finish the experiment. About 65 per cent gave the maximum shock voltage - a clear demonstration of the power of the situation. ${ }^{35}$

In a lesser-known component of Milgram's research program, he asked other participants to read about the study and its results and predict how they would have behaved had they been subjected to the experiment. ${ }^{36}$ These participants, who were fully aware of the profound impact of the situation, still underestimated it; most said they would have stopped the shocks. ${ }^{37}$ They could not override their dispositionist tendency to believe that they were not the type of people to administer the apparently lethal shock.

The pressure to obey falls into a category of especially strong situational stressors termed "visceral factors" by George Loewenstein. ${ }^{38}$ Visceral factors (e.g., hunger, pain, and sexual desire) produce a direct hedonic impact on the individual and are thus incredibly powerful in causing short-term behavioural change. And, because they lie deep in System 1, people "underweigh, or even ignore, visceral factors that they will experience in the future, have experienced in the past, or that are experienced by other people." 39

34. Stanley Milgram, "Behavioral Study of Obedience" (1963) 67:4 J Abnormal \& Soc Psychol 371.

35. Ibid at 372,376 .

36. Stanley Milgram, Obedience to Authority: An Experimental View (New York: Harper \& Row, 1974) [Milgram, Obedience]; George Loewenstein, "Out of Control: Visceral Influences on Behavior” (1996) 65:3 Organizational Behaviour \& Hum Decision Processes 272 at 282.

37. Milgram, Obedience, supra note 36 at 27-31.

38. Loewenstein, supra note 36.

39. Ibid at 272 . 
Loewenstein applied this failure to account for visceral factors to explain several longstanding psychological paradoxes. ${ }^{40}$ On the more mundane end, people seem perpetually overconfident in their ability to wake up early because they are unable to simulate the hedonic averseness of a 5:00 a.m. wakeup call. ${ }^{41}$ And, more importantly, hedonic factors explain research on outbreaks of sexually transmitted infections which occur because "much unprotected sex occurs in the heat of the moment but that people can't remember or predict what the heat felt like and so are unprepared to deal with it." ${ }^{\prime 2}$ In short, these hedonic forces are automatic and unconscious, and thus difficult to account for, both in ourselves and others.

\section{APPLIED SOCIAL AND COGNITIVE PSYCHOLOGY ON EYEWITNESS MEMORY AND FALSE CONFESSIONS}

When it comes to the study of wrongful convictions, perhaps the most important development to come from social and cognitive psychology is research on eyewitness memory and false confessions. We address these topics in order.

That eyewitnesses can make identification errors is a well-documented phenomenon in the justice system. Psychologists have spent decades investigating the causes of such high-stakes errors, focusing on phenomena that fall within the realm of cognitive psychology (those affecting our memorial and attentional processes) and social psychology (those that result from interaction between two or more people). ${ }^{43}$ This research has been referred to as the "gold standard" of psychological research applied to the legal context. ${ }^{44}$ Many of the experiments that have established the causes of eyewitness misidentification have arisen from real-life cases.

Take the well-known case of Ronald Cotton's wrongful conviction in the United States. ${ }^{45}$ When an African-American male broke into Jennifer Thompson's

40. On issues with underuse of contraception and self-protection against sexually transmitted infections, see e.g. ibid at 286-89. See also Dan Ariely \& George Loewenstein, "The Heat of the Moment: The Effect of Sexual Arousal on Sexual Decision Making" (2006) 19:2 J Behav Decision Making 87.

41. Loewenstein, supra note 36 at 281.

42. Ibid at 286 .

43. For a review, see United States, National Research Council, Committee on Science, Technology, and Law, Identifying the Culprit: Assessing Eyewitness Identification (Washington, DC: National Academies Press, 2014).

44. State v Henderson, 208 NJ 208 (2011) [State v Henderson], citing State v Chun, 194 NJ 54 (2008). See also Saks \& Spellman, supra note 24 at 26.

45. Jennifer Thompson-Cannino, Ronald Cotton \& Erin Torneo, Picking Cotton: Our Memoir of Injustice and Redemption (New York: St. Martin's Press, 2009). 
college apartment and sexually assaulted her, Thompson made sure to study her attacker's face in order to make an identification. Later, Thompson carefully examined a photograph lineup and picked the one she thought looked most like her attacker. She chose Cotton's photograph. Afterward, the police did a live line up, and, again, Thompson chose Cotton. She was confident she recognized him. At trial, Thompson was completely confident that she recognized Cotton as her attacker. This confidence was misplaced. In fact, Thompson incorrectly identified Cotton and failed to recognize Bobby Poole, the actual attacker as established by post-conviction DNA testing. ${ }^{46}$ In retrospect, several questions arise from Cotton's wrongful conviction. How could Thompson so confidently misidentify her attacker after studying his face so carefully? How could she fail to identify Poole, her actual attacker? Psychological science offers answers to these questions: a combination of unconscious and situational factors that, unfortunately, can influence anyone.

Memory's key vulnerability is that it is reconstructive. This means that instead of keeping an accurate recording of information about what has happened to us, we instead piece memory fragments together with suggestion from the environment. In turn, we are all vulnerable to a wide variety of memory errors and distortions. Jennifer Thompson exhibited one such memory error by picking Cotton out of the live lineup at the station and again at trial, a phenomenon called "unconscious transference." ${ }^{47}$ Put another way, Jennifer Thompson did recognize Ronald Cotton when she saw him in the live lineup because she had seen him before in the photograph lineup and mistakenly believed she recognized him from the attack. ${ }^{48}$ As we shall discuss below, identifying such transference in cross-examination is difficult (and perhaps impossible) because the witness is unaware that it occurred. Indeed, psychologists have demonstrated across a multitude of studies that unconscious transference can result in innocent people being mistaken for the actual perpetrator. ${ }^{49}$

Memory-distorting, post-event information can be introduced by talking about an event as well. In a ground-breaking study by Elizabeth Loftus and colleagues, participants viewed a series of photographs depicting an automobile-

46. Ibid at 213.

47. David F Ross et al, "Unconscious Transference and Mistaken Identity: When a Witness Misidentifies a Familiar but Innocent Person" (1994) 79:6 J Applied Psychol 918.

48. Thompson-Cannino, Cotton \& Torneo, supra note 45.

49. Elizabeth F Loftus, "Unconscious Transference in Eyewitness Identification" (1976) 2:1 Law \& Psychol Rev 93; Kenneth A Deffenbacher, Brian H Bornstein \& Steven D Penrod, "Mugshot Exposure Effects: Retroactive Interference, Mugshot Commitment, Source Confusion, and Unconscious Transference" (2006) 30:3 Law \& Hum Behavior 287. 
pedestrian accident and then answered questions about what they remembered. ${ }^{50}$ Some of the questions contained misleading information; the experimenters, for example, asked: "Did another car pass the red Datsun while it was sitting at the stop sign?" when the red Datsun was actually sitting at a yield sign. ${ }^{51}$ Later, the researchers asked what type of traffic sign the red Datsun was waiting at - a yield sign or a stop sign. Instead of noticing the incorrect information (that the sign was a stop sign), participants incorporated it into their memory for the event. When asked what the traffic sign was, many participants answered: "a stop sign," when they actually saw a yield sign. Over the years, many other psychologists have studied this "misinformation effect" and found it to be robust and generalizable. ${ }^{52}$

Beyond our tendency to form and maintain inaccurate memories, the manner in which our memories are tested can dictate how we respond. As such, it should come as no surprise that psychologists have investigated how photograph and live lineups can lead to better or worse eyewitness identifications. Any such factors are categorized as either estimator variables or system variables. ${ }^{53}$ Estimator variables refer to situational and dispositional factors that may influence eyewitness memory, including normal memory processes such as decay, stress, or cross-racial identification impairment. ${ }^{54}$ They are outside the control of investigators. System variables, on the other hand, refer to factors (often situational) that investigators can control, such as the lineup design or administration. If we think of eyewitness identifications as real-world memory tests, then we want to ensure that an eyewitness "passes" - that is, makes the correct identification. To do this, we want to make sure the test is well-designed by ensuring that the witness makes the correct identification based on their memory for what they saw, and make sure the test is administered fairly by ensuring that the investigator does not influence

50. Elizabeth F Loftus, David G Miller \& Helen J Burns, "Semantic Integration of Verbal Information into a Visual Memory” (1978) 4:1 J Experimental Psychol: Hum Learning \& Memory 19.

51. Ibid at 20 .

52. For a review, see Elizabeth F Loftus, "Planting misinformation in the human mind: A 30-year investigation of the malleability of memory" (2005) 12:4 Learning \& Memory 361.

53. Brian L Cutler, Steven D Penrod \& Todd K Martens, "The reliability of eyewitness identification: The role of system and estimator variables" (1987) 11:3 Law \& Hum Behavior 233.

54. See Kenneth A Deffenbacher et al, "A Meta-Analytic Review of the Effects of High Stress on Eyewitness Memory" (2004) 28:6 Law \& Hum Behavior 687; Christian A Meissner \& John C Brigham, "Thirty Years of Investigating the Own-Race Bias in Memory for Faces: A Meta-Analytic Review” (2001) 7:1 Psychol Pub Pol'y \& L 3. 
the answer in any way. In other words, the situational-contextual factors that may bias the identification should be minimized.

Like with those participants in Milgram's study, who read the results but failed to grasp the consequences, the situational and unconscious nature of memory has also resulted in demonstrable myths. For example, in a recent nationally representative survey of Americans, Daniel Simons and Christopher Chabris found that many respondents still endorsed incorrect beliefs about human memory. ${ }^{55}$ For example, 63 per cent endorsed the view that memory works like a video camera, 78 per cent thought that hypnosis enhances memory, and 48 per cent believed that memory is permanent (i.e., that the content of the memory does not change over time). The pervasion of such myths is extremely troubling because there is decades of scientific research disproving each of these.

While it may be tempting to conclude that "mistakes happen," and that the structure of the justice system attempts to correct for such mistakes, it is remarkably troubling that we are rarely able to account for our own errors. Indeed, Jennifer Thompson was completely confident about her inaccurate memory of her attacker, to the point where she failed to recognize the real assailant. Psychologists have long investigated whether we can evaluate memories to detect whether they are true or false. Generally speaking, we are unable to tell the difference between our own true and false memories. ${ }^{56}$ Further, observers — even expert psychologistscannot say if a particular memory is accurate or inaccurate. ${ }^{57}$ As such, a full understanding of what dispositional and situational factors may lead to memory distortion is extremely important for legal decision making.

The lack of observability of memory does not mean that people will always misunderstand how their memories work. Rather, misunderstanding is most likely to occur when naïve psychological theories (held by the general public) run counter to reality. ${ }^{58}$ For instance, some memory phenomena may be intuitive (e.g., poor lighting impairs memory formation) and, in some cases, anecdotal experience

55. Daniel J Simons \& Christopher F Chabris, "What People Believe about How Memory Works: A Representative Survey of the U.S. Population” (2011) 6:8 PLoS ONE e22757.

56. Alan Scoboria et al, "A mega-analysis of memory reports from eight peer-reviewed false memory implantation studies" (2017) 25:2 Memory 146.

57. Daniel M Bernstein \& Elizabeth F Loftus, "How to Tell If a Particular Memory Is True or False” (2009) 4:4 Persp on Psychological Sci 370; Faigman, Monahan \& Slobogin, supra note 18 at 432-34.

58. Nisbett \& Wilson, supra note 31 at 233 (calling these "a priori theories about the causal connection between stimulus and response" (ibid)). See also Donald G Dutton \& Arthur P Aron, "Some Evidence for Heightened Sexual Attraction Under Conditions of High Anxiety" (1974) 30:4 J Personality \& Soc Psychol 510. 
may be representative of actual memory operation (e.g., some individuals may be able to call to mind instances in which they observed something while under great stress and then failed to recall it later). However, lay psychology is often wrong. Recall, for instance, the stocking-choosers in Nisbett and Wilson's study who assumed their preferences were driven by the quality of the product rather than its position. Similarly, intuitions about how our memories work will often be wrong; we cannot directly examine these unconscious processes. ${ }^{59}$

Confessions are another form of evidence for which psychological science provides a more complete understanding. Once again, findings in this area are often counterintuitive. Despite the expectation that an innocent person would never confess to a crime he or she did not commit, lab studies contradict this intuition. In a 1996 study, Saul Kassin and Katherine Kiechel recruited participants to complete a seemingly mundane typing task with a partner. ${ }^{60}$ There was one rule: do not press the "Alt" key on the keyboard, or the computer would crash and data would be lost. Unbeknownst to the participants, the computer was designed to crash after several minutes of typing. When the experimenter accused the participants of pressing the key, the majority of participants, feeling the pressure of the situation, agreed to sign a statement acknowledging their guilt (i.e., a confession).

While such laboratory settings are qualitatively different than actual police interrogations, variations on the Kassin and Kiechel paradigm have shown that people continue to confess falsely when the experimental realism is increased,

59. See Tanja Rapus Benton et al, "Eyewitness Memory is Still Not Common Sense: Comparing Jurors, Judges and Law Enforcement to Eyewitness Experts" (2006) 20:1 Applied Cognitive Psychol 115. These researchers presented eyewitness experts, jurors, and judges with thirty system and estimator variables that influence eyewitness memory and asked participants to rate whether the statements were "generally true," "generally false," or to state "I don't know." Experts, jurors, and judges showed high agreement for some estimator and system variable factors. For example, the majority of all three groups said that the wording of questions (situational), child suggestibility (dispositional), and alcoholic intoxication (situational) all affect eyewitness memory. Overall, however, jurors significantly disagreed with experts on 87 per cent of the issues, and judges significantly disagreed with experts on 60 per cent of the issues. This study illustrates that properly accounting for the dispositional and situational factors in eyewitness memory is difficult and likely exists on a continuum of understanding. While some jurors and judges may agree with knowledgeable experts, there is a large amount of variation across factors, which underlines the importance of not relying on our own assessment of our knowledge.

60. Saul M Kassin \& Katherine L Kiechel, "The Social Psychology of False Confessions: Compliance, Internalization, and Confabulation” (1996) 7:3 Psychological Sci 125. 
for example, by imposing consequences for confessing. ${ }^{61}$ In fact, it stands to reason that if people confess to researchers in a laboratory, real life situations, in which suspects have more at stake, are under great stress, and are the subject of hours-long police interrogations, only increase the pressure on an innocent person to confess.

Although a number of dispositional factors put someone at risk for a false confession (such as certain clinical diagnoses, youth, and low IQ), ${ }^{62}$ there also numerous situational factors that do so. For example, investigators can induce false confessions with a variety of interrogation techniques, such as offering (false) inculpatory evidence, ${ }^{63}$ refusing to accept denials, ${ }^{64}$ or implying leniency for confessing. ${ }^{65}$ Beyond that, though, the tenets of social psychology predict (and indeed have been supported by research) that people will falsely confess for more simple reasons, such as a basic decision-making task of avoiding the immediate, unpleasant situation of an interrogation, without considering the ramifications of confessing. ${ }^{66}$ To summarize, people do falsely confess to crimes, and many of the reasons people do so are situational in nature.

\section{UNCONSCIOUS NEGLECT AND DISPOSITIONISM IN EXPERT EVIDENCE LAW}

As a general matter, lay theories of human behavior, as well as legal theories, recognize the role of the situation only when it is palpable or when theorists are particularly motivated to do so. And even then, only the most salient or satisfying elements of the situation are considered. Otherwise, disposition is presumed to govern. ${ }^{67}$

61. See e.g. Robert Horselenberg, Harald Merckelbach \& Sarah Josephs, "Individual Differences and False Confessions: A Conceptual Replication of Kassin and Kiechel” (1996) 9:1

Psychol Crime \& Law 1; Allison D Redlich \& Gail S Goodman, "Taking Responsibility for an Act Not Committed: The Influence of Age and Suggestibility” (2003) 27:2 Law \& Hum Behavior 141.

62. Saul M Kassin et al, "Police-Induced Confessions, Risk Factors and Recommendations" (2010) 34:1 Law \& Hum Behavior 3 [Kassin et al, "Police"]; Lindsay C Malloy, Elizabeth P Shulman \& Elizabeth Cauffman, "Interrogations, confessions, and guilty pleas among serious adolescent offenders" (2014) 38:2 Law \& Hum Behavior 181.

63. Kassin \& Kiechel, supra note 60.

64. Kassin et al, "Police," supra note 62.

65. Melissa B Russano et al, "Investigating True and False Confessions Within a Novel Experimental Paradigm” (2005) 16:6 Psychological Sci 481.

66. Kassin et al, "Police," supra note 62 at 14.

67. Hanson \& Yosifon, "The Situational Character," supra note 9 at 6. 
A growing number of legal scholars have come to recognize the power of the situation and have begun to integrate it into modern legal thought. ${ }^{68}$ These scholars have remarked that traditional patterns of legal scholarship tend to parallel patterns of human thought, which are intuitively dispositionist and neglectful of the unconscious. ${ }^{69}$ Expert evidence law should not be exempted from this analysis. Shunning situationism in evidence law for a more cognitively facile model of human behaviour comes at a terrible cost: People are put in jail (or worse) when they do not belong there, and the real perpetrators are free to do more harm.

Under the beyond the ken standard, scientific evidence must be "likely to be outside the experience and knowledge of a judge or jury" ${ }^{30}$ in order to be admissible in court. In Canada, this requirement is incorporated into $R v$ Mohan's criterion that the evidence be "necessary to enable the trier of fact." This requirement typically proves insurmountable for experts seeking to opine about eyewitness memory and false confessions, unless they couch their opinion in some disposition the accused possesses. ${ }^{72}$ As we describe above in Part I, characterizing these expert opinions as within the ken reflects a fundamental misunderstanding of science.

In this Part, we examine Canadian eyewitness memory and false confessions jurisprudence. In this jurisprudence, we identify a dispositionist thread. Prior to that, however, it is instructive to consider " $[\mathrm{t}]$ he high-tide mark in the Supreme

68. See e.g. ibid; Hanson \& Yosifon, "The Situation," supra note 9; Thaler \& Sunstein, supra note 10.

69. Hanson \& Yosifon, "The Situational Character," supra note 9 at 6.

70. Mohan, supra note 2 at 23; See also Sidney N Lederman, Alan W Bryant \& Michelle K Fuerst, The Law of Evidence in Canada, 4th ed (Markham: LexisNexis Canada, 2014) at 795-99. See also the discussion at supra note 2.

71. Mohan, supra note 2 at 23, citing $R v$ Abbey, [1982] 2 SCR 24 at para 44, 138 DLR (3d) 202. See also $R v D(D), 2000$ SCC 43 at paras 21, 57, [2000] 2 SCR $275[D(D)]$; $R v K(A)$ (1999), 45 OR (3d) 641 at paras 90-92, 176 DLR (4th) 665 (CA). For a review, see Cunliffe, supra note 3 at 299-302. Besides necessity, expert evidence must also meet three other preconditions. It must be logically relevant, not be subject to other exclusionary rules, and be proffered by a properly qualified expert (with a threshold level of impartiality). Novel or contested scientific evidence must also possess a threshold level of reliability. Evidence that passes that threshold is then subjected to the trial judge's residual discretion to exclude evidence when its costs (e.g., time, prejudice) to the trial process outweigh its benefits. Reliability and impartiality are factored into this discretionary weighing. For a more thorough summary, see White Burgess Langille Inman v Abbott and Haliburton Co, 2015 SCC 23 at paras 23-24, [2015] 2 SCR 182 [White Burgess].

72. McIntosh, supra note 6 at para 20; Rv Pearce, 2014 MBCA 70 at paras 89, 95, 310 Man R (2d) $14[$ Pearce $]$. 
Court of Canada's liberal approach to the admissibility of expert evidence": ${ }^{73}$ the admission of Battered Woman Syndrome ("BWS") ${ }^{74}$ evidence in $R v$ Lavallee. $^{75}$ BWS provides a useful counterpoint to similar psychological evidence that is excluded because it rests firmly on a disposition - a syndrome-rather than on situational factors. Expert evidence about BWS is usually proffered to support self-defence claims of women who kill their partners in the context of a long pattern of domestic violence. We suggest that BWS has found success at the admission stage-whereas similar evidence has not-because it fits with the courts' dispositionist instincts. But, as some jurists have noted, ${ }^{76}$ restricting such evidence to a disposition may unduly constrain self-defence claims.

The accused in Lavallee shot and killed her perpetually abusive husband. ${ }^{77}$ She pleaded self-defence with BWS supporting the reasonableness and necessity of her actions. ${ }^{78}$ As the name suggests, BWS can result from physical, emotional, and sexual abuse against the female partner in a close relationship. It is associated with a feeling of learned helplessness, from which the battered woman perceives a lack of alternatives to remaining in the abusive relationship. ${ }^{79}$ In Lavallee, the defence witness, a psychiatrist, explained why the accused, as a sufferer of BWS, might stay in a relationship with an abusive partner and why she might be particularly wary of severe and imminent violence..$^{80}$ The psychiatrist's evidence demonstrated why it would be reasonable for the accused to believe her life was at risk in a way that would not have been apparent to an outside observer. ${ }^{81}$

The Supreme Court of Canada ("SCC") rejected the Crown's argument that the psychiatrist's evidence was unnecessary for dealing with a subject that was within the ken of the judge and jury. ${ }^{82}$ Justice Wilson, writing for the Court, noted that there is a belief-one that the Crown sought to take advantage of - that judges do not need expert psychological evidence because they are

73. Cunliffe, supra note 3 at 292.

74. Battered Woman Syndrome is now often referred to as Battered Spouse Syndrome or Battered Partner Syndrome in the research literature. We use the first term to reflect its use in the primary case we consider: $R v$ Lavallee, [1990] 1 SCR 852, 67 Man R (2d) 1 [Lavallee]. See Martha Shaffer, "The Battered Woman Syndrome Revisited: Some Complicating Thoughts Five Years After R. v. Lavallee" (1997) 47:1 UTLJ 1.

75. Lavallee, supra note 74.

76. See infra note 87 and the accompanying text.

77. Lavallee, supra note 74 at paras 2-11.

78. Ibid at paras 26-27.

79. Ibid at para 58 .

80. Ibid at paras 41-52.

81. Ibid at paras 45-74.

82. Ibid at paras 32-40. 
"thoroughly knowledgeable about 'human nature' and that no more is needed. They are, so to speak, their own experts on human behaviour." ${ }^{33}$ She found that such confidence in the trier of fact's understanding of human nature was misguided. Rather, myths and stereotypes pervade the topic of domestic abuse; judges and juries might reason that the battered woman should simply leave the abusive relationship. As a result, an expert was necessary to understand the mental state of a battered woman in the case of Lavallee.

Evidence about BWS is now frequently admitted by courts in Canada, ${ }^{84}$ the United States, ${ }^{85}$ and Australia. ${ }^{86}$ But BWS presents a dispositional view of a situation's (i.e., domestic violence) impact. In other words, BWS is a psychological condition, something internal to the sufferer that guides her actions. In many cases, it may fail to capture the full range of situations that deeply impact a person's behaviour. Indeed, eight years after Lavallee (in a case in which the admissibility of BWS was conceded), Justice L'Heureux-Dubé expressed concern that this syndromization of domestic violence could ultimately undermine self-defence claims: "It is possible that those women who are unable to fit themselves within the stereotype of a victimized, passive, helpless, dependent, battered woman will not have their claims to self-defence fairly decided." ${ }^{87}$

83. Ibid at para 33 .

84. Rv Kahypeasewat, 2006 SKPC 79, 284 Sask R 55; $R v$ Young, 2008 BCCA 393, 260 BCAC 166; $R v M(M A)$, [1998] 1 SCR 123, 155 DLR (4th) 513 [M(MA)]. Tellingly, a discussion of BWS can often save expert evidence that would otherwise not meet the necessity standard. For instance, parties often struggle to admit evidence explaining why a complainant or witness delayed in reporting abuse. See $D(D)$, supra note 71 . But similar evidence is admissible when couched in BWS. See $R v$ Reid (2003), 65 OR (3d) 723 at para 46, 18 CR (6th) 350 (CA) [Reid]. Justice Moldaver notes: "In my view, Dr. Jaffe's evidence was admissible but only for a limited purpose. It should have been restricted to a brief description of the nature and root causes of the conditions known as Battered Women's Syndrome and Post-traumatic Stress Disorder and their possible effects on disclosure patterns." For similar reasoning, see $R v F(D S)$ (1999), 43 OR (3d) 609, 169 DLR (4th) 639 (CA) [F(DS)]; $R v M(R C)$ (2005), 67 WCB (2d) 499, 2005 CarswellOnt 4901 (WL Can) (Sup Ct); $R v S(J P)$ (2001), 50 WCB (2d) 161, 2001 CarswellOnt 1794 (WL Can) (CA) [S(JP)].

85. For a review, see Kaye, Bernstein \& Mnookin, supra note 2 at 157-64.

86. See Heather Douglas, "Social Framework Evidence: Its Interpretation and Application in Victoria and Beyond" in Kate Fitz-Gibbon \& Arie Freiberg, eds, Homicide Law Reform in Victoria: Retrospect and Prospects (Sydney: Federation Press, 2015) 94; Australia, National Domestic and Family Violence Benchbook (2017), online: <dfvbenchbook.aija.org.au>.

87. $M(M A)$, supra note 84 at para 40 . See also Shaffer, supra note 74 . 
It is important to note that, in many cases, the expert is not providing a diagnosis of BWS ${ }^{88}$ Rather, the expert is giving framework evidence; ${ }^{89}$ he or she is explaining how BWS works, rather than saying, with some degree of medical certainty, that the accused is suffering from BWS. The same can be said for expert evidence about eyewitness memory and false confessions, for which experts do not seek to opine that a witness misremembered or that an accused falsely confessed. Rather, they explain the psychological processes, relevant to the current case, that give rise to those phenomena. But, as we argue in the following two sections, these experts are almost always excluded because there is no eyewitness misidentification or false confession syndrome.

\section{EYEWITNESS MEMORY}

The question of admitting or excluding expert evidence about eyewitness memory starts - and usually ends - with the Court of Appeal for Ontario's decision in $R v$ McIntosh. ${ }^{90}$ The Crown's case in McIntosh primarily consisted of three eyewitnesses. These witnesses identified the accused individuals as the perpetrators of a violent robbery at a dry-cleaning business. At trial, the defendants sought to tender the evidence of Dr. Daniel Yarmey, a cognitive psychologist specializing in memory. Dr. Yarmey would have opined on several aspects of the identifications. These included: limitations of eyewitnesses' ability to view and encode the faces of the defendants, lower accuracy related to cross-racial identification, ${ }^{91}$ the photograph lineup used by the police, misconceptions jurors may have about photograph lineups, difficulties with "in-dock" identifications, and the investigating officers' compliance with police procedures for identifications. ${ }^{93}$

In finding the expert evidence unnecessary, Justice Finlayson characterized the science as common sense and simply the "normal experience" of a trier of

88. See e.g. Reid, supra note 84 at para 46; $S(J P)$, supra note 84 at para 5; $F(D S)$, supra note 84 at para 36. In Australia, see Douglas, supra note 86.

89. For a lucid description of the distinction between framework and diagnostic evidence, see Faigman, Monahan \& Slobogin, supra note 18.

90. McIntosh, supra note 6. McIntosh has been widely followed to exclude both evidence of memory experts and confessions experts. See $R v$ Frimpong, 2013 ONCA 243, 106 WCB (2d) 326 [Frimpong]. On confessions experts, see Pearce, supra note 72; Rv Jeanvenne, 2011 ONSC 7244 at para 27, 102 WCB (2d) 322 [Jeanvenne].

91. The defendants in McIntosh were Black, and of the eyewitnesses, one was also Black, one was East Asian, and one was Caucasian. See McIntosh, supra note 6 at para 27.

92. In-dock identifications are those made in court. The Supreme Court of Canada in $R v$ Hibbert confirmed such identifications are almost completely devoid of probative value. See $R v$ Hibbert, 2002 SCC 39, [2002] 2 SCR 445 [Hibbert].

93. McIntosh, supra note 6 at para 11 . 
fact. ${ }^{94}$ Indeed, we all have memories and we all have experienced forgetting. ${ }^{95}$ In coming to this conclusion, Justice Finlayson drew an express distinction between inadmissible situational (and unconscious) effects on memory and admissible dispositional characteristics suggesting "that it would be a different situation if a Crown witness had demonstrated remarkable memory ... expert evidence might be admissible to show that the witness is an autistic savant and that such exceptional memory feats are often associated with this syndrome." 96

The problem with the reasoning in McIntosh is that memory is not part of our normal conscious experience. ${ }^{97}$ Rather, memory processes are unconscious and thus unobservable. As we describe above in Part I, the best way to reliably research these processes is to conduct randomized studies that manipulate one variable (e.g., the race of the faces to be remembered), and then to observe the resulting effects without directly peering into the black box of the participant's mind. Cognitive psychologists have performed these studies and can inform the trier of fact about

94. Ibid at para 20.

95. This view has received some academic support. See Stuesser, supra note 4 at 545 (noting "I suggest that much of what is provided by the experts is intuitive").

96. McIntosh, supra note 6 at para 21. As we discuss in the following paragraphs, McIntosh is the leading case on eyewitness expertise and almost always operates to exclude such evidence. Justice Finlayson's situation-disposition distinction is rarely relied on, likely because eyewitnesses do not often demonstrate psychological disorders (i.e., disposition). But see $R v M(B)$ (1998), 42 OR (3d) 1 at paras 100-101, 40 WCB (2d) 116 (CA). The Court of Appeal for Ontario noted that an expert's testimony about situational factors was inadmissible, except to the extent that it interacted with the fact that the witness was a child (a dispositional variable):

Some of Dr. Bray's testimony was of a similar nature and properly excluded by the trial judge such as her evidence about the effect of trauma on memory. However, other parts of her evidence, especially about very early childhood memory of sexual abuse, are outside the normal experience of the trier of fact (ibid at para 101).

More generally, our point is that both judges and juries are likely to misunderstand how memory processes work because those processes are not directly observable. In many cases, this will lead to them undervaluing the role of situational forces, as we describe in this Part.

97. For a similar argument, see Jennifer L Mnookin, "Constructing Evidence and Educating Juries: The Case for Modular, Made-In-Advance Expert Evidence About Eyewitness Identifications and False Confessions" (2015) 93:7 Tex L Rev 1811 at 1839:

The serious problem with this instruction is that it locates the relevant source of knowledge undergirding its point in 'ordinary human experience' rather than psychology or social-science research. It basically tells the jury members that if they have found in their ordinary experience that identifying people of other races can be harder, then they may consider that experience in their evaluation of the evidence in the case. But what if this is not the perceived experience of the jurors? (ibid). 
the unconscious memory processes that produce misidentifications. In a recent criminal trial, J. Don Read made precisely this point in expert testimony that was ultimately excluded because its subject matter was within the ken: "They respond to things that are, in a sense, outside of their awareness. How do I know? Because we can do the studies and demonstrate that they choose people at higher rates when you've made these manipulations." ${ }^{\text {98 }}$

The irony is that the eyewitness identifications themselves are only admissible because they are made unconsciously; ${ }^{99}$ courts recognize the unconscious processes that underlie identifications when exempting them from general bar on opinion evidence, but they then lose track of this insight when excluding experts from opining on those identifications. That is to say, the rule that permits eyewitness identifications - the lay opinion rule-recognizes that the source of eyewitness identifications is unconscious and non-verbalizable cognitive processes. Thus, witnesses may give their opinion (e.g., "he's the guy I saw robbing the bank") the verbalizable outcome of unconscious processes — rather than providing the facts that underlie that opinion-the unconscious processes. In the leading lay opinion case, Justice Dickson, as he then was, gave precisely this rationale for the rule: Lay opinion is permissible when it is made "without conscious ratiocination." ${ }^{100}$ In the context of eyewitness experts, courts have recognized the difficulty this presents: "While the circumstances surrounding the witness's identification can be subject to scrutiny in cross-examination, many of the more subjective processes that have led to it are impossible to expose in this fashion." 101 Courts, however, seem to lose track of these insights when deciding whether to admit experts to opine on eyewitness identifications.

98. $R v$ Clark, 2016 ABCA 72 (Trial transcript), online: <osf.io/sed $4 \mathrm{n}>$ at 244 [Clark, ABQB].

99. Graat v R, [1982] 2 SCR 819 at para 52, 144 DLR (3d) 267 [Graat]. See also Chin, Tomiska $\& \mathrm{Li}$, supra note 31.

100. Graat, supra note 99. See also Elwin v Nova Scotia Home for Coloured Children, 2013 NSSC 196 at para 88, 332 NBR (2d) 35. The Nova Scotia Supreme Court also couched the rule in terms of lack of consciousness: "Put another way, a witness may give an opinion where the facts upon which the opinion is based are assessed on a subconscious level" (ibid).

101. Rv Miaponoose, 30 OR (3d) 419 at para 11, 32 WCB (2d) 161. See also Kent Roach, "Unreliable Evidence and Wrongful Convictions: The Case for Excluding Tainted Identification Evidence and Jailhouse and Coerced Confessions" (2007) 52:2 Crim LQ 210 at 216. 
The role of unconscious processes leading to misidentifications in Canada was made evident in the wrongful conviction of Thomas Sophonow. ${ }^{102}$ In the inquiry that followed Sophonow's release, Justice Cory highlighted the role of unconscious transference in the wrongful conviction. One of the Crown's key witnesses did not initially select Sophonow out of the lineup but did select him in a subsequent lineup after seeing him in the newspaper. ${ }^{103}$ In fact, Justice Cory relied heavily on Elizabeth Loftus's research when coming to his conclusion about the proper role of eyewitness memory experts in the courtroom:

I would recommend that judges consider favourably and readily admit properly qualified expert evidence pertaining to eyewitness identification. This is certainly not junk science. Careful studies have been made with regard to memory and its effect upon eyewitness identification. Jurors would benefit from the studies and learning of experts in this field. ${ }^{104}$

Justice Cory recommended that trial judges "readily admit" eyewitness memory experts over fifteen years ago. As a testament to the power of unconscious neglect, only one reported trial decision has adopted Justice Cory's advice. ${ }^{105}$ Instead, McIntosh is still widely followed. In $R v$ Perlett, for example, the Court of Appeal for Ontario excluded Elizabeth Loftus's testimony, which would have explained the effect of extreme stress (from a home invasion) on memory. ${ }^{106}$ The court followed McIntosh, deciding that stress and memory were "within jurors' normal experience." 107 The court made this finding in spite of research directed to them by Loftus showing that nearly 50 per cent of Americans laboured under the myth that stressful events are better remembered than non-stressful

102. Manitoba, Department of Justice, "The Inquiry Regarding Thomas Sophonow" (Winnipeg: Queen's Printer, 2010), online: <digitalcollection.gov.mb.ca/awweb/ pdfopener?smd $=1 \& \mathrm{did}=12713 \& \mathrm{md}=1>[$ Manitoba, DOJ]. See also the role of eyewitness identification in the wrongful conviction of Leighton Hay, Rv Hay, 2013 SCC 61, [2013] 3 SCR 694; Robert Baltovich, $R v$ Baltovich (2004), 73 OR (3d) 481, 65 WCB (2d) 397 (CA) [Baltovich]; Anthony Hanemaayer, $R v$ Hanemaayer, 2008 ONCA 580, 78 WCB (2d) 399; Réjean Hinse, $R v$ Hinse (1994), 64 QAC 53, 24 WCB (2d) 130; and Romeo Phillion, see $R$ $v$ Phillion, 2009 ONCA 202, 65 CR (6th) 255 [Phillion, ONCA]. There may be fewer (as a proportion) confirmed cases of wrongful convictions based on eyewitness identifications in Canada as compared to the United States because sexual offences carry shorter sentences in Canada, thus leaving less time for the exoneration process.

103. Manitoba, DOJ, supra note 102 at 59.

104. Ibid at 18 [emphasis added].

105. $R v$ Henderson, 2009 MBQB 101, 239 Man R (2d) 69.

106. $R v$ Perlett (2006), 82 OR (3d) 89 at para 95, 71 WCB (2d) 210 (CA).

107. Ibid at para 108 . 
ones. ${ }^{108}$ In 2013, a differently constituted panel of the Court of Appeal followed $M c I n t o s h$ and excluded expert evidence about unconscious transference and other memory processes. ${ }^{109}$

\section{E. FALSE CONFESSIONS AND MR. BIG OPERATIONS}

In a popular episode of Star Trek: The Next Generation, the Cardassian Gul Madred attempts to demonstrate mastery over his prisoner, Captain Jean-Luc Picard, by forcing him to report a patently false claim: that there are five spotlights shining on him when there are only four. Jean-Luc withstands sleep-withdrawal, promises of numerous benefits, and the lie that his crew has been killed, and steadfastly refuses to adopt Madred's narrative. Finally, Jean-Luc appears to waiver when Madred offers him a final bargain of "[a] life of ease... of reflection and intellectual challenge," 110 as opposed to life in prison. The only catch: Picard must say there are five lights. At that moment, Cardassian forces above Madred's head order Picard's release. Reflecting on these moments, Picard and a colleague share the following conversation:

One thing I didn't put in my report... at the very end, he offered me a choice... between a life of comfort... or more torture... all I had to do was say there were five lights.

You didn't say it...

No... but I was going to. I was ready to tell him anything he wanted... anything at all. But more than that, I was beginning to believe there were five lights. ${ }^{111}$

This description of Jean-Luc's plight evokes comparisons to the Milgram experiments and Loewenstein's interpretation of them. Jean-Luc, like the participants in Milgram's studies, did not suffer a mental disorder; there was no dispositional force at play. In fact, he was one of Star Fleet's finest officers. Yet, just as 65 per cent of Milgram's participants administered the highest shock possible, even Picard wavered under pressure. Similarly, under the intense visceral pressures of interrogation, intelligent adults will make false self-incriminatory

108. Ibid at para 103. One such study is Richard S Schmechel et al, "Beyond The Ken? Testing Jurors' Understanding of Eyewitness Reliability Evidence” (2006) 46:2 Jurimetrics 177.

Indeed, stress has a reliable negative impact on memory in most cases. For a recent review, see Grant S Shields et al, "The Effects of Acute Stress on Episodic Memory: A Meta-Analysis and Integrative Review" (2017) 143:6 Psychological Bulletin 636.

109. Frimpong, supra note 90 at paras 23-28.

110. Frank Abatemarco, "Chain of Command, Part II" Star Trek: The Next Generation, online: $<$ www.st-minutiae.com/resources/scripts/237.txt>.

111. Ibid [emphasis added]. 
statements about even the most heinous crimes. Demonstrating this outwardly counterintuitive phenomenon, Brandon Garrett examined 250 wrongful convictions in the United States in which the accused was exonerated by DNA evidence. Of these 250 miscarriages of justice, forty involved false confessions. ${ }^{112}$ Only four of those exonerees brought expert evidence about their confession at trial, and where brought, this evidence was largely disregarded. ${ }^{113}$

As we discuss above in Part $\mathrm{I}(\mathrm{C})$, research into false confessions has found that they are driven by both situation and disposition. ${ }^{114}$ In Garrett's US study, he described a host of situational factors, including verbal abuse and other powerful inducements. ${ }^{15}$ As for disposition, 65 per cent of those who gave false confessions were mentally disabled, underage, or both. ${ }^{116}$ In Canada, the confession in $R v$ Unger revealed a similar pattern. ${ }^{117}$ Kyle Unger gave a confession after being subjected to a undercover police tactic known as a Mr. Big operation (described below in this Part) in which he was promised a lucrative position in a fictional organized crime group. Unger was young (approximately twenty) and poor; the gang's inducements were difficult to turn down. ${ }^{118}$ About twelve years later, DNA evidence called the conviction into doubt and the ministerial review process began. ${ }^{119}$ The Crown ultimately withdrew the charges.

Despite these troubling findings, Canadian courts almost always find that situational forces bearing on the reliability of a confession are within the ken. ${ }^{120}$ In doing so, their reasoning processes are remarkably similar to those found in McIntosh; they draw a distinction between admissible evidence about a mental disorder suffered by the accused (i.e., disposition) and inadmissible evidence about the situation in which the confession was made. In $R v$ Dietrich, for instance,

112. Garrett, "Substance," supra note 21 at 1060.

113. Ibid at 1102-1106.

114. See the sources in supra notes 60-65.

115. Garrett, "Substance," supra note 21 at 1065-66.

116. Ibid at 1064-65.

117. (1993), 85 Man R (2d) 284, 20 WCB (2d) 395 (MB CA).

118. Saul M Kassin et al, "Police-Induced Confessions, Risk Factors, and Recommendations: Looking Ahead" 34:1 Law \& Hum Behaviour 49 at 50.

119. Rv Hart, 2014 SCC 52 para 62, [2014] 2 SCR 544 [Hart].

120. For a discussion of false confessions in the Canadian context, see Brian L Cutler, Keith A Findley \& Timothy E Moore, "Interrogations and False Confessions: A Psychological Perspective" (2014) 18:2 Can Crim L Rev 153; Timothy E Moore \& C Lindsay Fitzsimmons, "Justice Imperiled: False Confessions and the Reid Technique" (2011) 57:4 Crim LQ 509; Moore \& Wasser, supra note 3. For its role in false confessions, see Bruce MacFarlane, "Convicting the Innocent: A Triple Failure of the Justice System" (2006) 31:3 Man LJ 403 at 472-78. 
the Court of Appeal for Ontario found the testimony of three psychiatrists was properly admissible. ${ }^{121}$ Those psychiatrists testified that the accused had "a psychopathic personality and that both false confessions and the truth would be consistent with his personality." ${ }^{122}$ As we now describe, the outcome is very different when the expert would be called to explain the situational, visceral factors that contribute to false confessions.

The SCC's foundational confessions case, $R v$ Oickle, seemed to presage the admissibility of expert evidence about visceral factors. ${ }^{123}$ Expert evidence was not at issue in Oickle. Rather, the Court enunciated the current rule for the admission of confessions, which centres on voluntariness. ${ }^{124}$ In its inquiry, however, the Court acknowledged a vast collection of research and literature describing the situational and dispositional forces that result in false confessions. ${ }^{125}$ Writing for the majority, Justice Iacobucci made several important observations about false confessions. He accepted that they occur frequently. ${ }^{126} \mathrm{He}$ also remarked that they are "counterintuitive" because lay people struggle to understand why someone would confess to a crime he or she did not commit. ${ }^{127}$ Justice Iacobucci then surveyed a leading taxonomy for false confessions and suggested that a variety of situational and dispositional factors produce false confessions. ${ }^{128}$

With strong language regarding both the significance and widespread misunderstanding of false confessions among triers of fact, Oickle appeared to open the door for expert evidence regarding the reliability of confessions. For instance, Gary Trotter (now a Justice of the Court of Appeal for Ontario) predicted that post-Oickle, such evidence should meet Mohan's necessity requirement:

121. Rv Dietrich (1970), [1970] 3 OR 725 at paras 39-56, 11 CRNS 22.

122. Ibid at para 39. The Ontario Supreme Court in $R v$ Harley followed this view. See $R v$ Harley (1985), 16 WCB 78, 1985 CarswellOnt 2477 (WL Can) (SC).

123. $R v$ Oickle, 2000 SCC 38, [2000] 2 SCR 3 [Oickle].

124. Ibid at para 47.

125. The accused in Oickle confessed to several instances of arson. His confession, however, did not come easily; the police misled him about the accuracy of a polygraph that he failed and threatened to investigate his girlfriend should he not confess. Justice Iacobucci, writing for the majority, enunciated a new common law confessions rule, couching the analysis in whether the confession was involuntary and thus unreliable (see ibid at paras 81-84, 94-103). Based on this new test, Oickle's confession was voluntary and thus admissible (ibid at para 72). Justice Arbour, in dissent, agreed with the majority's statement of the law. However, she found that the police tactics ran afoul the confessions rule, and thus Oickle's confession was involuntary (ibid at paras 106-42).

126. Ibid at para 35 .

127. Ibid at para 34 .

128. Ibid at paras 38-44. 
After Oickle, the necessity threshold should be met for expert evidence on false confessions. ... It is a counter-intuitive proposition. It suggests an unusual person, an unusual scenario, or perhaps both. Without assistance in unraveling this issue, the conduct of the accused may be beguiling to a juror in the same way as the battered woman who does not leave her abuser. ${ }^{129}$

Importantly, Trotter seemed to place disposition ("an unusual person") and situation ("an unusual scenario") on the same footing. His prediction, however, was not borne out by the case law.

$R v$ Phillion represented one such opportunity to admit expert evidence about false confessions but was ultimately decided on other grounds. ${ }^{130}$ Phillion was referred to the Court of Appeal for Ontario as a possible miscarriage of justice. ${ }^{131}$ The conviction was based on an eyewitness identification and recanted confession. ${ }^{132}$ At the reference, the defence tendered the expert evidence of two psychologists, who opined that a combination of the situation and Phillion's distinctive personality traits cast doubt on his confession. ${ }^{133}$ The Court of Appeal decided the expert evidence was not fresh evidence because similar evidence had been admitted at trial. ${ }^{134}$ Still, the court issued dispositionist dicta saying that the personality evidence should be admissible: "in cases such as this where the reliability of a confession is in issue, expert evidence regarding an accused's personality traits that is relevant to and probative of the issue will be admissible." 135 Mr. Phillion succeeded on other grounds, and his case is now considered an instance of wrongful conviction based on faulty eyewitness identification and false confession. ${ }^{136}$

129. Trotter, supra note 3 at 193 [emphasis added].

130. Phillion, ONCA, supra note 102.

131. Ibid at paras 9, 45-47.

132. Phillion v R (1977), [1978] 1 SCR 18, 74 DLR (3d) 136.

133. Phillion, ONCA, supra note 102 at paras 202-207.

134. Ibid at paras 236-37.

135. Ibid at para 218.

136. "Introduction: The Unsolved Murder of Leopold Roy," Innocence Canada, online: <www. innocencecanada.com/exonerations/romeo-phillion $>$. The same line was drawn in $R v$ Leslie, 2008 ONCJ 666, 87 WCB (2d) 509. The court expressly distinguished the allowable expert testimony about mental disorder from Dietrich. It disallowed expert evidence from psychologist Timothy Moore, characterizing it as common sense drawn from human experience: "What Dr. Moore is describing, essentially, is a scenario which inherently be characterized as a combination of threats, inducements and oppressive circumstances. That is not the domain of specialized knowledge but, rather, a confirmation that one must assess with common sense and human experience" (ibid at para 10). 
$R v$ Pearce, a 2014 decision of the Manitoba Court of Appeal, drew a bright line between inadmissible situational factors and admissible dispositional characteristics. ${ }^{137}$ The accused in Pearce contacted the police to offer assistance in a murder case that had gone cold. After an interview and a polygraph examination, he was cleared as a suspect. He then came forward yet again and, after an extensive interrogation, confessed to the murder. ${ }^{138}$ Pearce later contended that the confession was false. He was upset and suicidal because he had just been outed as homosexual and had learned he might have AIDS, he had been abusing painkillers, and the police had coerced him into making the confession. ${ }^{139}$ In support of its false confession theory, the defence tendered the evidence of two expert psychologists who opined on both dispositional and situational factors.

The dispositional testimony-the results of a personality test given to Pearce-was inadmissible because it was unreliable but not because it was unnecessary. ${ }^{140}$ The situational evidence was disallowed because it was unnecessary and the expert was not impartial. ${ }^{141}$ As to necessity, the Court of Appeal held that the situational factors were well within the jury's ken:

The appellant said when he confessed he was emotionally upset to the point of being suicidal because his homosexuality had been revealed and he was fearful he may have AIDS. Such stress was transitory in nature and not a distinctive behaviourial characteristic outside the experience and knowledge of the jury. ${ }^{142}$

The experiences in Pearce and the cases that proceeded it represent a "natural experiment" testing whether Canadian courts are indeed dispositionist. In these cases, expert evidence about the reliability of a confession is introduced as both dispositional and situational. The results are clear: Courts, without expressly remarking on the distinction they are making, prefer the dispositional evidence. The same pattern holds in the US case law. ${ }^{143}$

Issues of false confessions do not only arise in conventional police interrogations. Rather, many of the same visceral factors are at play when suspects

137. Pearce, supra note 72.

138. Ibid at paras 7-30, 139.

139. Ibid at paras 26-28.

140. Ibid at para 88 .

141. Ibid at paras 38-40, 91-98.

142. Ibid at para 85 .

143. See People v Kowalski, 492 Mich 106 (2012) (mirrors Pearce). The American Psychological Association, in its amicus curiae brief, remarked on the illogical distinction between admissible dispositionist evidence and inadmissible situational evidence. See People v Kowalski, 492 Mich 106 (2012) (Brief of the American Psychological Association in Support of Appellant), online: www.apa.org/about/offices/ogc/amicus/kowalski.pdf> at 18 . 
confess to undercover officers as part of an investigative tactic known as a Mr. Big operation. ${ }^{144}$ In these operations, a suspect is approached by undercover officers and offered to carry out some small criminal jobs for a fictional criminal organization. As the charade progresses, the suspect moves up the ladder in the organization. This suspect, often someone of limited means and social contacts, is lavished with expensive gifts, dinners, flights across the country, and friendship. Along the way, he or she may be shown examples of other members who disobey or mislead the organization and suffer bodily harm as a result. It all culminates in a meeting with the titular Mr. Big. At this point, Mr. Big may ask the suspect to admit any crimes he or she has committed because they may be a liability to the organization. Alternatively, Mr. Big may say he has evidence of a crime and the suspect should admit it as an indication of loyalty. ${ }^{145}$

Mr. Big stings engage incredible situational pressures. In fact, the SCC recently acknowledged the psychological literature concerning these forces in enunciating a new exclusionary rule for Mr. Big confessions. ${ }^{146}$ In $R v$ Hart, the Court held that such confessions are presumptively inadmissible, with the onus on the Crown to demonstrate that their probative value exceeds their prejudice. ${ }^{147}$

One source of prejudice comes from the visceral factors of fear and authority (as in the Milgram study). ${ }^{148} \mathrm{R} v \mathrm{Orr}^{149}$ provides an example of such pressures and courts' willingness to disregard them. In that case, the Court of Appeal for British Columbia drew an analogy between the plight of human trafficking victims and those subject to Mr. Big stings. The court said that expert evidence about both are unnecessary because " $[t]$ here is persuasive authority for the proposition that ordinary, fair-minded members of Canadian juries are capable of weighing common motivations and basic human emotions such as fear of reprisal and

144. For a review of the Mr. Big strategy, see Hart, supra note 119 at paras 56-62; $R v$ Osmar, 2007 ONCA 50 at paras 1-5, 84 OR (3d) 321 [Osmar]; Timothy E Moore, Peter Copeland \& Regina A Schuller, "Deceit, Betrayal and the Search for Truth: Legal and Psychological Perspectives on the 'Mr. Big' Strategy" (2009) 55:3 Crim LQ 348 at 351-53. In Australia, see Tofilau $v$ R, [2007] HCA 39, 231 CLR 396.

145. Hart, supra note 119 at para 60.

146. Ibid at paras 68-77.

147. Ibid at paras 84-118.

148. See Moore, Copeland \& Schuller, supra note 144 at 378-93 (Moore, Copeland and Schuller lucidly employ a psychological analysis to describe the dangers the dispositionism in evaluating Mr. Big confessions).

149. 2015 BCCA 88, 120 WCB (2d) 51. 
dependence." ${ }^{150}$ In other words, the situational forces at play in human trafficking and elaborate police stings are both within the ken.

Mr. Big stings also trigger the intense "need to belong" and the corresponding fear of alienation. Roy Baumeister and Mark Leary studied this need, finding it can be as strong as many physiological needs and can cause intense emotional pain because humans are inherently social animals. ${ }^{151}$ This force was at play in Hart itself: The suspect, at the behest of the undercover officers, became estranged from his wife. ${ }^{152}$ He thus relied on his new 'friends' as his only source of social contact. ${ }^{153}$ This is yet another social situational force that a jury is likely to underestimate due to the dispositionist heuristic that only guilty people confess. ${ }^{154}$

Despite the acknowledgement in Hart that Mr. Big confessions are inherently unreliable, there is little reason to think expert evidence about these confessions will be permitted any time soon. Appellate decisions have consistently held that the psychological forces that impact the reliability of a Mr. Big confession are within the trier of fact's ken. ${ }^{155}$ And while the Hart doctrine is a step in the right direction for excluding unreliable confessions, it still represents a high bar. ${ }^{156}$ Compounding this problem (and unlike with eyewitness memory), there are still no standard judicial instructions designed to educate the trier of fact about visceral forces that cause false confessions. In the following Part, we outline our recommendation for an approach to unreliable Crown evidence. Reflecting on the above discussion, the following Part combines exclusionary rules with measures designed to educate the trier of fact about the situational and unconscious forces they are constitutionally inclined to neglect.

150. Ibid at para 73. The court in $\mathrm{Orr}$ also relied on McIntosh for the general notion that the behavioural sciences are not beyond the ken (ibid at para 67).

151. Roy F Baumeister \& Mark R Leary, “The Need to Belong: Desire for Interpersonal Attachment as a Fundamental Human Motivation” (1995) 117:3 Psychological Bulletin 497.

152. Hart, supra note 119 at paras 136-38.

153. The Supreme Court ultimately found Hart's confession was inadmissible for a variety of reasons, including the social alienation factor. See ibid at paras 127-47.

154. Moore, Copeland \& Schuller, supra note 144 at 383-84.

155. Osmar, supra note 144; $R v$ Bonisteel, 2008 BCCA 344, 79 WCB (2d) 506; Jeanvenne, supra note 90 . The court in Jeanvenne relied on McIntosh for the notion that courts should be reluctant in "abdicating the jury's fact finding responsibilities to experts in the field of behavioural sciences" (ibid at para 27). This may further reinforce the degree to which the exclusion of experts in these areas is driven by the same psychological misapprehensions.

156. See text accompanying infra note 201. 


\section{COUNTERING UNCONSCIOUS NEGLECT AND DISPOSITIONISM}

We have argued that courts frequently over-apply Mohan's necessity requirement because they misunderstand the psychology of eyewitness memory and confessions; these courts undervalue the assistance experts offer in explaining the situational and unconscious processes that produce mistaken identifications and false confessions. This does not mean, however, that admitting an expert will always be the appropriate "procedural corrective." ${ }^{157}$ Indeed, experts carry a cost, both in terms of court time and any fee the expert may charge. ${ }^{158}$ Moreover, framework (as opposed to diagnostic) evidence is less likely to vary on a case-by-case basis, which suggests that reforms focused on enhanced judicial instructions and education may be of particular value. Still, a more scientifically informed conceptualization of the fact-trier's ken informs how courts should regulate eyewitness and confession evidence. ${ }^{159}$

157. Dufraimont, supra note 3 at 278.

158. Moreover, there is no consensus in the psychological literature regarding whether judges or experts are more effective at educating the jury about eyewitness memory issues. For example, some research finds that experts are effective. See Brian L Cutler, Hedy R Dexter \& Steven D Penrod, "Expert Testimony and Jury Decision Making: An Empirical Analysis" (1989) 7:2 Behav Sci \& L 215. Other research finds that judicial instructions are ineffective. See Edith Greene, "Judge's Instruction on Eyewitness Testimony: Evaluation and Revision" (1988) 18:3 J Applied Psychol 252. However, a recent, well-designed study found no difference between the two safeguards. See Kristy A Martire \& Richard I Kemp, "The Impact of Eyewitness Expert Evidence and Judicial Instruction on Juror Ability to Evaluate Eyewitness Testimony" (2009) 33:3 Law \& Hum Behavior 225. Still, this area has not reached a consensus, and there may be circumstances - likely those where several complicated memory phenomena are engaged - where expert evidence is preferable. And, even in studies that found no ultimate effect on verdict, more sensitive measures like memory for the testimony or instructions benefited from expert evidence (ibid at 231). Note also that the efficacy of expert evidence is highly plausible. See $D(D)$, supra note 71 at para 31. Chief Justice McLachlin, in dissent, suggested that jurors would benefit from understanding how underlying psychological processes work. For a similar point, see Copeland, supra note 3 at 203 (noting that "[j] urors are much more likely to be sensitive to the factors affecting the reliability of eyewitness identification evidence if they understand how and why these factors affect reliability"). For a review, see Dufraimont, supra note 3 at 297-309; Fiona Leverick, "Jury Instructions on Eyewitness Identification Evidence: A Re-Evaluation” (2016) 49:3 Creighton L Rev 555.

159. For other well-considered reform recommendations, see Roach, supra note 101; Angela Baxter, "Identification Evidence in Canada: Problems and a Potential Solution" (2007) 52:2 Crim LQ 175. 
Besides unconscious neglect and dispositionism, other cognitive biases render eyewitness and recanted evidence difficult for the trial judge to manage. For instance, Michael Saks and Barbara Spellman recently noted that judges labour under what psychologists call the "curse of knowledge." 160 In other words, judges face understandable difficulty in the meta-cognitive task of placing themselves in the mind of the jury because the judges have a great deal more experience with eyewitness identifications and false confessions. As a result, they can be expected to overestimate the jury's understanding of these issues. By similar processes, they are also inclined to overestimate their own ability to explain these complex phenomena to juries. ${ }^{161}$

In light of unconscious neglect, dispositionism, and the curse of knowledge, an improved system for managing eyewitness identifications and confessions should be more specific and directive. It should require that trial judges engage with the factors that produce unreliable identifications and confessions. Moreover, the same biases underlie both of these forms of evidence. Therefore, the lessons gleaned from unreliable eyewitnesses may inform the confessions doctrine and vice versa.

As we describe above in Part II(B), the SCC in Hart recently developed a new procedure for admitting Mr. Big confessions. The Court rendered them presumptively inadmissible, with the onus on the Crown to demonstrate the confessions' reliability. Similarly, in Oickle, the Court confirmed that traditional police-induced confessions should be excluded if there is a reasonable doubt about their voluntariness. ${ }^{162}$ There is no reason why a similar exclusionary mechanism should not exist in response to eyewitness identifications, ${ }^{163}$ which are also remarkably prejudicial because of their unconscious and situational character. ${ }^{164}$

But, while the responses to unreliable confessions in Oickle and Hart represent rational responses, they still allow evidence that the factfinder is predisposed to misunderstand to be admitted. This suggests there is still a role for

160. Saks \& Spellman, supra note 24 at 18.

161. David Dunning, Chip Heath \& Jerry M Suls, "Flawed Self-Assessment: Implications for Health, Education, and the Workplace" (2004) 5:3 Psychological Sci in Pub Interest 69.

162. Oickle, supra note 123 at para 68.

163. State $v$ Henderson, supra note 44.

164. Dufraimont, supra note 3 at 321-26 (making a similar argument for a more coherent approach to unreliable Crown evidence). However, as we describe below in this Part, we would not make all eyewitness identifications prima facie inadmissible. There are many reasons to distinguish between Mr. Big confessions and eyewitness identifications, including the sheer force of situational and unconscious pressures in Mr. Big confessions, the legal system's (in)tolerance for oppressive investigative tactics, and the sheer number of cases including eyewitness identification evidence. 
educative measures in some cases. For instance, in Oickle itself, the accused faced intense situational pressures to confess. ${ }^{165}$ The majority and dissent disagreed over whether the confession was voluntary. If there can be reasonable disagreement about the mere voluntariness of a confession, it stands to reason that the jury should be thoroughly educated about the psychological forces that could have rendered the confession unreliable but voluntary. There are, however, no standard jury instructions in such circumstances. ${ }^{166}$

In the remainder of this Part, we provide two pragmatic suggestions for how the Canadian common law of evidence should evolve. First, we discuss a doctrine recently developed by the New Jersey Supreme Court in New Jersey $v$ Henderson. ${ }^{167}$ In Henderson, the court empowered a special master to hear evidence about eyewitness memory from several leading psychologists. The court accepted the master's findings and devised a pre-trial procedure to consider the eyewitness identification factors at issue and potentially to exclude the identification. This doctrine-developed to reflect the science of memory—is well-suited to regulate evidence that courts are inclined to underestimate. Second, we suggest that Canadian courts more willingly admit expert evidence about false confessions.

Henderson represents one of the most rigorous common law approaches to the problem of unreliable eyewitness identifications to date. To obtain a Henderson pre-trial hearing, the initial onus is on the accused to demonstrate some evidence of suggestion in the identification. ${ }^{168}$ Then, in the pre-trial hearing, the prosecution must establish the reliability of the identification. As part of this inquiry, the trial judge is directed to consider a non-exhaustive list of system and estimator factors. ${ }^{169}$ If the trial judge finds that there is a "very substantial likelihood of irreparable misidentification," 170 he or she must suppress the identification. Even if the identification is admissible, the Henderson court prescribed extensive judicial instructions that drill down into each factor that was engaged. ${ }^{171}$ These instructions are to be given regardless of whether the eyewitness

165. Oickle, supra note 123 at paras 6-10.

166. Dufraimont, supra note 3 at 273-74.

167. State $v$ Henderson, supra note 44.

168. Ibid at $922-24$.

169. Ibid at 920-22. Recall that estimator factors are situational factors outside the investigator's control, like cross-racial identification. System factors are controllable, like the administration of the lineup. See text accompanying supra notes 53-54.

170. State $v$ Henderson, supra note 44 at 920.

171. Ibid at 925-27. 
issue seems common sense. ${ }^{172}$ Further, instructions may be given during the trial to educate the jury on key eyewitness issues as they emerge. ${ }^{173}$

In the face of psychological processes that courts regularly underestimate and misunderstand, the more specific and directive Henderson procedure presents an advantage. ${ }^{174}$ Notably, the psychology of eyewitness memory is no longer an issue the court may disregard; rather, the trial judge must (as in the current confessions regime) provide an express holding in many cases. The Henderson court made this same point, noting that "estimator variables would no longer be ignored." 175 In Canada, the only realistic means for excluding an eyewitness identification is under the trial judge's highly discretionary power to exclude evidence when its risk of prejudice outweighs its probative value. ${ }^{176}$ This is typically reserved for highly prejudicial and nearly valueless in-dock identifications. ${ }^{177}$ Adopting an exclusionary rule based on defined factors and principles aligns the eyewitness rules with the development of similar rules in Oickle and Hart.

A more concrete eyewitness regime may also provide efficiencies. For instance, the spectre of an inadmissible identification would encourage police to follow guidelines rigorously for extracting identifications (e.g., by using double-blind procedures and constructing lineups using photographs of individuals similar to the description provided by witnesses). ${ }^{178}$ It can be easy to take shortcuts in the course of an investigation. Stronger rules (or any rules, for that matter) may help deter such behaviour and may lead to fewer issues at trial as well as less

172. Ibid at 924-25 (noting that "[e]ven with matters that may be considered intuitive, courts provide focused jury instructions" (ibid at 924)).

173. Ibid at 924 .

174. For a similar suggestion, see Dufraimont, supra note 3 at 321-23.

175. State $v$ Henderson, supra note 44 at 922.

176. Baxter, supra note 159 at 184-89.

177. Ibid. But, note that one serious difficulty with asking trial judges to exclude unreliable identifications is that they may be ill-equipped to make that determination. Indeed, even expert psychologists cannot accurately opine on the reliability of a particular identification. See Mnookin, supra note 97 at 1828-36.

178. For instance, guidelines were not followed in $R v$ Clark because the identification was not double-bind. See $R v$ Clark, 2016 ABCA 72 at para 42, 128 WCB (2d) 585 [Clark, ABCA]. The Henderson court suggested that deterring improper police conduct is an important role for rules that regulate the admission of eyewitness identifications. See State $v$ Henderson, supra note 44 at 919 . 
emphasis on a judge's instructions to the jury, which research finds can often be ineffective. ${ }^{179}$

Moreover, the Canadian eyewitness jurisprudence is replete with trial decisions overturned and retrials ordered for deficient jury instructions. ${ }^{180}$ While useful model instructions are available, ${ }^{181}$ and while courts have been warned to use specific and thorough instructions, ${ }^{182}$ trial judges retain considerable discretion in crafting their instructions (and this problem is even greater in bench trials, as we discuss later in this Part). In $R v$ Richards, for instance, the Court of Appeal for Ontario ordered a new trial, in part, because the trial judge failed to canvass sufficiently the dangers of cross-racial misidentifications in his instructions. ${ }^{183}$ Under Henderson, that would have been required at first instance. ${ }^{184}$ Again, judges may fail to bring home the frailty of eyewitness memory because of unconscious neglect. It may also be difficult for them to remove themselves from their own view of the case. In $R v$ Baltovich, for instance, insufficient instructions about eyewitness memory coincided with a charge that "as a whole, ... unduly promoted the case for the Crown and effectively ignored and denigrated the case for the defence." ${ }^{185}$ As noted in the beginning of this Part, judicial education programs may wish to highlight the often-counterintuitive forces that render eyewitness identifications unreliable.

This brings us to expert evidence, a measure that may also relieve some pressure from the trial judge's instructions. Unlike with its directions regarding pre-trial hearings and jury charges, the Henderson court left the admission of expert witnesses as a discretionary measure. Here, it is important to note that Canadian and US courts substantially diverge in their admission of eyewitness

179. See the sources in supra note 158. See also Chantelle M Baguley, Blake M McKimmie \& Barbara M Masser, "Deconstructing the Simplification of Jury Instructions: How Simplifying the Features of Complexity Affects Jurors' Application of Instructions" (2017) 41:3 Law \& Hum Behavior 284.

180. $R v$ Hibbert (1996), 128 WAC 277 at para 52, 78 BCAC 277; $R v$ Richards (2004), 70 OR (3d) 737, 62 WCB (2d) 11 (CA) [Richards]; Baltovich, supra note 102 at paras 77-83; $R v$ Tebo (2003), 57 WCB (2d) 588 at para 19, 175 CCC (3d) 116 (CA); $R v$ Brown, 2007 ONCA 71 at para 19, 72 WCB (2d) 313; $R c$ Proulx (1992), 76 CCC (3d) 316 at paras 46-155, [1992] RJQ 2047 (CA); $R v$ Brand (1995), 27 WCB (2d) 203 at para 7, 80 OAC 396.

181. National Judicial Institute, "Model Jury Instructions" (2014), online: <www.nji-inm.ca/ index.cfm/publications/model-jury-instructions $>[\mathrm{NJI}]$.

182. Rv Canning, [1986] 1 SCR 991, 30 DLR (4th) 767.

183. Richards, supra note 180 at para 32.

184. State v Henderson, supra note 44 at 926.

185. Baltovich, supra note 102 at para 113. 
memory experts. In the United States, courts are increasingly likely to admit such experts. ${ }^{186}$ However, as we reviewed in Part II(A,) McIntosh represents a de facto bar to such evidence in Canada.

We suggest that Canadian courts cautiously admit expert evidence about unreliable identifications. In making this decision, courts may consider several questions concerning the case against the accused. For instance, are issues of eyewitness identification central to the case? ${ }^{187}$ If the case against the accused hinges on an identification, then the court may wish to ensure the fact-trier is thoroughly informed about the psychological issues at play. Further, are any aspects of the identification especially vulnerable to misunderstandings about human memory? Here, courts can leverage a large body of research on misconceptions about eyewitness memory. This research indicates which aspects of memory are particularly counterintuitive due to their unconscious and situational character. For example, one large meta-analysis (a statistical summary of several other studies) found that 50 per cent of potential jurors are mistaken about the effect of race on face memory. ${ }^{188}$

If an identification rests on one or more of these especially powerful misconceptions, it may be a particularly appropriate case for expert evidence. ${ }^{189}$ More generally, there is reason to believe that experts may be more effective than judges at conveying psychological information. Generally, listeners are sensitive

186. Saks \& Spellman, supra note 24 at 121 . For a review of the US position, see Henry F Fradella, "Why Judges Should Admit Expert Testimony on the Unreliability of Eyewitness Testimony" (2007) 2:1 Fed Cts L Rev 1.

187. See e.g. Paciocco, supra note 3 at 344 . Paciocco observes that " $[w]$ hen judging 'necessity', focus should not be solely on the subject-matter of the opinion, per se, nor solely on the knowledge of the trier of fact. Necessity should be judged in light of the particular evidence and circumstances of the case" (ibid). See also Gary Edmond \& Kent Roach, "A Contextual Approach to the Admissibility of the State's Forensic Science and Medical Evidence" (2011) 61:3 UTLJ 343 at 363.

188. Sarah Desmarais \& J Don Read, "After 30 Years, What Do We Know about What Jurors Know? A Meta-Analytic Review of Lay Knowledge Regarding Eyewitness Factors" (2011) 35:3 Law \& Hum Behavior 200 at 203.

189. Such a system would also assist when judicial instructions are already likely to be long and complicated. Recent research finds that such instructions are ineffective. Baguley, McKimmie \& Masser, supra note 179. For a novel solution to the challenge of admitting expert evidence in a way that is not overly burdensome on the trial process, see Mnookin, supra note 97. Mnookin suggests that expert evidence "modules" can be prepared by a neutral body and played in trials when the relevant issue arises. For instance, if the case involves a holdup with a weapon, the trial judge may play a video of an expert psychologist opining on the research demonstrating that this factor impairs eyewitness memory. Similarly, cross-examination modules could also be presented. 
to the person delivering a message and may take the word of a psychological scientist more seriously. ${ }^{190}$ Then Chief Justice McLachlin, dissenting in $R v D(D)$, noted that jurors may benefit from hearing about the science behind psychological phenomena and that experts are better placed than judges at conveying that information. ${ }^{191}$ We are cognizant of the fact that mock-trial research has been inconclusive in determining whether expert testimony on eyewitness memory adds value. Still, very few studies have been conducted, and they have only explored a limited number of memory misconceptions that experts would opine on. ${ }^{192}$ Moreover, there is reason to believe that some misconceptions are more powerful than others.

A Henderson-inspired regime also assuages some of the issues that arise from bench trials. For instance, in $R v$ Clark, the Court of Appeal for Alberta upheld a trial judge's decision to exclude an expert psychologist. ${ }^{193}$ The trial judge reasoned that the expert was unnecessary because the judge's own knowledge was sufficient. He noted that he had been a lawyer for thirty-seven years and had taken several courses about the assessment of witnesses. ${ }^{194}$ In cases like Clark, accused parties may have justified concerns about the trial judges' knowledge of psychological research, especially in light of the fact that humans are constitutionally inclined to discount very real situational and unconscious forces. The accused in Clark at least had access to an expert who outlined the science for the trial judge in a voir dire, thus guaranteeing some part of the science was heard. In many cases, the accused does not even have that safeguard.

Had a Henderson hearing been available in Clark, the trial judge would have been directed to consider all of the psychological factors at play because the identification contained elements of suggestion. Indeed, when Clark was identified, the witness twice went through a photograph lineup without identifying him. He only made the identification when the officer drew his attention to

190. See Richard E Petty \& John T Cacioppo, Communication and Persuasion: Central and Peripheral Routes to Attitude Change (New York: Springer Science \& Business Media, 2012);

Robert B Cialdini, Influence: The Psychology of Persuasion (New York: Harper Collins, 2007) at 208-36.

191. $D(D)$, supra note 71 at para 31. Chief Justice McLachlin (dissenting) states:

The expert testified not only that many children do not report abuse immediately, but also went on to discuss the reasons why children may delay, based on the scientific literature. This additional information might reasonably have assisted the jury in deciding what, if anything, to infer from the delay, in a way that the proposed direction by the trial judge would not. If so, the evidence remained necessary (ibid).

192. See the sources in supra note 158.

193. See the sources in supra note 179.

194. Clark, ABQB, supra note 98 at 330-31. 
Clark's photograph. ${ }^{195}$ As a result, even if an expert had not been available, the judge would have had to consider eyewitness memory research and expressly rule on its applicability to the case. This is preferable to the current situation in Canada in which an accused has no guarantee at all about the extent to which the trial judge informed him or herself about the science of eyewitness memory. ${ }^{196}$

Regarding confessions, there are presently no standard National Judicial Institute jury instructions to educate about the case factors that may have produced a false confession. ${ }^{197}$ As a result, courts should consider admitting experts until the institutional knowledge has caught up to the science. As recommended by the SCC in two recent cases, ${ }^{198}$ this evidence may be narrowly circumscribed by the trial judge to focus on the aspects of the confession the jury is likely to misunderstand. This measure may save time and assuage the worry that the expert will exceed his or her role and usurp the role of the trier of fact.

The plight of Mr. Big confessors is even more severe because the evidence is not just inculpatory but also leverages the jury's dispositional instincts in a manner that puts the accused's character into question. ${ }^{199}$ For instance, in $R v$ Worme, a confession was admitted through the new Hart doctrine. The context to that admission was that prior to giving it, the accused was induced to engage in twenty-nine (notionally illegal) operations with the Mr. Big organization. ${ }^{200}$ This would almost surely impact the jury's ongoing evaluation of the case against the accused. Expert testimony heard during the trial may inoculate against such inferences in ways that instructions given at the end of the trial cannot. ${ }^{201}$

195. Clark, ABCA, supra note 178 at para 32.

196. $R v$ Gough, 2013 ONCA 137 at paras 36-37, 105 WCB (2d) 672.

197. Dufraimont, supra note 3 at 273-74; NJI, supra note 181 . Those responsible for drafting any such standard instructions may wish to take note of recent work demonstrating scientific consensus in many areas of confessions research. See Saul M Kassin et al, "On the General Acceptance of Confessions Research: Opinions of the Scientific Community” (2018) 73:1 Am Psychologist 63.

198. $R v$ Sekhon, 2014 SCC 15 at paras 46-48, [2014] 1 SCR 272; $R v$ Bingley, 2017 SCC 12 at paras 16, 29, [2017] 1 SCR 170. For a review, see Helena Likwornik, "Overstepping and Sidestepping: The Expert Evidence Dance" (2017) 35:4 Adv J 24.

199. Moore, Copeland \& Schuller, supra note 144; Hart, supra note 119 at paras 73-77.

200. $R v$ Worme, 2016 ABCA 174 at para 7, 36 Alta LR (6th) 1 . A re-trial was ordered in Worme because the investigating officer testified that Mr. Big confessions tend to be pure and truthful statements, and the trial judge did not allow him to be questioned on the fact that he had been involved in a sting that resulted in a wrongful conviction.

201. Dufraimont, supra note 3 at 273-74. 


\section{CONCLUSION}

In studies spanning thousands of participants, researchers find that people possess many deeply held misconceptions about how human psychology works. ${ }^{202}$ Despite these findings, trial judges regularly exclude psychological evidence because they believe it is common sense. They assume that the unconscious and situational character of eyewitness memory and induced confessions is common sense and within their own experience and that of the jury. But this is simply not the case; humans do not have conscious access to their unconscious mind and thus consistently discount the situational pressures that impact their thoughts, feelings, and behaviour.

In narrowing the ken to a more realistic model of what judges and jurors understand about human nature, we are expanding the range of topics on which experts should be admitted to opine. But that does mean that the floodgates are open. Over the past two decades, the SCC has increasingly emphasized the importance of gatekeeping invalid scientific evidence. ${ }^{203}$ And beyond scientific validity itself, the Court recently confirmed that an expert's partiality does not merely go to weight but can be grounds to exclude the expert. ${ }^{204}$ Further, the SCC has also emphasized the importance of carefully circumscribing the scope of expert evidence and policing that scope. ${ }^{205}$ Thorough scrutiny of expert evidence's validity and impartiality provides a more scientifically sound way to keep the gate against expert evidence about eyewitness memory and confessions. For instance, in Pearce, the personality test used by one of the experts to determine if the accused was prone to false confessions had not been scientifically validated. ${ }^{206}$ Further, issues of partiality arose in that case because the expert's submissions strayed from describing the science to advocacy. ${ }^{207}$ These reasons for excluding evidence are far sounder than the mistaken belief that the factors that produce false confessions are within the ken.

While it may be intimidating to confront long-held and deeply intuitive misconceptions of the trier of fact's ken, the benefits outweigh the disadvantages. Most significantly, unconscious neglect and dispositionism account for what has

202. Desmarais \& Read, supra note 188.

203. White Burgess, supra note 71 at para 20.

204. Ibid at para 40. But note that the Court established a high bar to exclude evidence for partiality.

205. For a review, see Jason M Chin \& Helena Likwornik, " $R v$ Bingley and the Importance of Scientifically Guided Legal Analysis” (2017) 43:1 Queen’s LJ 33.

206. Pearce, supra note 72 at para 88.

207. Ibid at paras 96-98. 
long been considered one of criminal law's greatest dangers: the risk of wrongful convictions. Those miscarriages of justice that have been identified-a number that grossly underestimates the total amount that exist—regularly tell the tale of a confident, but mistaken, eyewitness or a suspect seemingly acting against his or her interest by confessing to a crime. Once we accept that the fact-trier's ken is narrower than we thought, the path forward becomes much clearer. 